Reprod. Nutr. Dévelop., 1987, 27 (6), 1053-1062.

\title{
Mitotic activity in monkey and rat Leydig cells
}

\author{
J.-P. FOUQUET, Marie-Louise KANN
}

Laboratoire d'Histologie, Université René Descartes, 45, rue des Saints-Pères, 75270 Paris Cedex 06, France.

Summary. The testes of the monkey, Macaca fascicularis, from birth to adulthood and of rats from puberty to adulthood were examined by both light and electron microscopy to estimate the mitotic activity of the Leydig cells. In monkeys, mitotic activity was measurable only in neonates : $2.3 \%$ in Leydig cells and $0.4 \%$ in fibroblast-like cells. From measurements of ${ }^{3} \mathrm{H}$-thymidine incorporation, mature Leydig cells were labeled in neonates $(2 \%)$ and adult animals $(1 \%)$. The labeling indices were significantly increased with increasing time after isotope exposure, and some pairs of labeled cells were found. In prepubertal ( 28 days of age) and pubertal ( 45 days of age) rats, mitotic indices were 2 and $0.2 \%$, respectively, in the Leydig cells and 0.4 and $0.1 \%$ in fibroblast-like and myoid cells, respectively. Mitoses were not detected in postpubertal rats at 63 days of age. Taken together, these results demonstrate the self-renewal ability of mature Leydig cells during normal development.

\section{Introduction.}

In most mammals, the Leydig cells differentiate in the fetal testis, regress at birth and develop definitively at puberty (Christensen, 1975). Numerous observations suggest that Leydig cells originate by differentiation from stem cells (Christensen, 1975 ; Gondos et al., 1977 ; Camatini and Franchi, 1981 ; Fouquet et al., 1983, 1984 ; Prince, 1984 ; Schulze, 1984). The concept of Leydig cell precursors has recently received morphological and functional support (Kerr et al., 1985a,b ; Morris et al., 1986 ; Jackson et al., 1986 ; Risbridger et al., 1987). It is also believed that Leydig cells are able to divide (Christensen, 1975). Certainly, interstitial cells show mitotic activity during normal development (Roosen-Runge and Anderson, 1959 ; Baillie, 1961 ; Hitzeman, 1962 ; Gondos et al., 1977) and this activity increases during various experimental conditions (Chemes et al., 1976 ; Aoki and Fawcett, 1978 ; Kerr et al., 1979 ; Christensen and Peacock, 1980). However, mitotic Leydig cells have been actually identified only in cryptorchid rats (Kerr et al., 1979). On the other hand, studies on tritiated thymidine incorporation in young rats have shown either labeled (Niemi and Kormano, 1964 ; Okada, 1970) or unlabeled (Orth, 1982) Leydig cells. Thus, it appears that the mitotic activity of Leydig cells is in need of careful analysis.

A recent light microscope radioautographic study in monkeys demonstrated ${ }^{3} \mathrm{H}$-thymidine-labeled Leydig cells but failed to identify the mitotic figures 
(Fouquet and Raynaud, 1985). The present paper now provides ultrastructural evidence for the existence of mitoses in the mature Leydig cells of monkeys and rats during normal development.

\section{Material and methods.}

1. Animals. - Fifteen male monkeys (Macaca fascicularis) raised in captivity were used, classified according to age and testicular development into five groups (Fouquet et al., 1984) : neonates, 1 to 3 months; infants, 6 to 24 months ; prepubertals, 36 to 48 months (meiosis); pubertals, 48 to 54 months (spermiogenesis) ; adults, 56 to 70 months; $n=3$ for each period. Besides, 2 neonates and 2 adults, which had been injected with ${ }^{3} \mathrm{H}$-thymidine and studied previously by light microscope radioautography (Fouquet and Raynaud, 1985) were re-examined by electron microscope radioautography as well.

Twelve male Sprague-Dawley rats were used and 3 stages of development studied: prepubertal, 28 days (meiosis); pubertal, 45 days (spermiogenesis); postpubertal, 63 days (complete spermatogenesis) ; $n=4$ for each stage.

2. Tissue preparation. - As previously described (Fouquet et al., 1984 ; Fouquet, 1987), the testes of young monkeys up to 24 months old and biopsies of adult testes were fixed by immersion in a glutaraldehyde-paraformaldehyde mixture. The testes of older monkeys ( $>24$ months) and rats were perfused with the same fixative. The blocks were post-fixed in $\mathrm{OsO}_{4}$ and embedded in Epon. In each animal the blocks were selected at random ; semi-thin sections and adjacent thin sections were prepared systematically to correlate light and electron microscope observations.

3. Quantitative analysis. - For each block, one semi-thin section was used for counting the number of interstitial cells and mitoses. These measurements were performed at 1,000 $\times$ magnification using oil-immersion optics and an eyepiece grid containing a square lattice of 100 points. The Leydig cells were identified by their epithelioid shape, spherical nucleus, cytoplasm intensely stained with toluidine blue and the presence of lipid droplets. The thin sections were used to ascertain the identity of the mitotic cells. According to Christensen (1975), only cells with a predominant smooth endoplasmic reticulum (SER) were classified as mature or fully differentiated Leydig cells. Possible precursors or immature Leydig cells with few SER cisternae were classified as fibroblast-like cells. About 1,000 Leydig cells/animal were scored after analysis of 16 blocks/adult or pubertal monkey, 5 blocks/neonate, infant or prepubertal monkey and 4 blocks/rat.

4. Radioautography. - For light microscopy, 1- $\mu \mathrm{m}$ semi-thin sections were dipped in Ilford K5 emulsion (Ilford Ltd., Ilford, U.K.), diluted $1: 2$ and exposed at $4^{\circ} \mathrm{C}$ for 14 weeks. Radioautographs were developed in D 19 Kodak for 4 min at $18{ }^{\circ} \mathrm{C}$ and fixed $10 \mathrm{~min}$ in $30 \%$ sodium thiosulfate. For electron microscopy, 1/4- $\mu \mathrm{m}$ sections were dipped in Ilford $1 /$ emulsion diluted 1:3. After 12-month exposure, the radioautographs were developed in Kodak D 19 B. 
The interstitial cells with $\geqslant 3$ silver grains over the nucleus were considered to be labeled since non-specific background grains were extremely few in number $\left(<0.5\right.$ grain $\left./ 1,000 \mu \mathrm{m}^{2}\right)$. The labeling index at each time interval was expressed as the percentage of labeled nuclei for an average of 1,000 Leydig cells and for 10,000 other interstitial cells including fibroblasts, myoid cells and macrophages, counted as described above in the quantitative analysis.

TABLE 1

Labeling indices (1.i.) of interstitial cells after ${ }^{3} \mathrm{H}$-thymidine injection in monkeys.

\begin{tabular}{|c|c|c|c|c|c|c|c|c|}
\hline \multirow{3}{*}{$\frac{\text { Age }}{\text { Time after isotope exposure }}$} & \multicolumn{4}{|c|}{ Neonates } & \multicolumn{4}{|c|}{ Adults } \\
\hline & \multicolumn{2}{|c|}{55 days } & \multicolumn{2}{|c|}{68 days } & \multicolumn{2}{|c|}{63 months } & \multicolumn{2}{|c|}{70 months } \\
\hline & 4 hrs & 15 days & $1 \mathrm{hr}$ & 7 days & $1 \mathrm{hr}$ & 9 days & $1 \mathrm{hr}$ & 10 days \\
\hline Leydig cells & 2.20 & $3.89^{*}$ & 1.78 & 2.53 & 1.02 & 1.55 & 0.71 & $1.72^{*}$ \\
\hline Other cells & 1.02 & $1.57^{* * *}$ & 0.93 & $1.34^{* *}$ & 0.11 & $0.18^{*}$ & 0.11 & $0.29^{* * *}$ \\
\hline
\end{tabular}

5. Statistical analysis. - In each animal, the percentage and mitotic index of the Leydig cells (LC) and other interstitial cells were calculated from the total number : number of LC/total number of interstitial cells $\times 100$, number of mitotic $\mathrm{LC} /$ total number of LC $\times 100$. When these percentages were subjected to a $\mathrm{Chi}^{2}$-test, no significant differences were found among the animals in any of the age groups. Therefore, the final values were expressed as the mean $( \pm$ SEM) for each group and a one-way analysis of variance was used to determine significant quantitative differences. For comparison of the labeling indices at different times after isotope exposure in each animal, a $\mathrm{Chi}^{2}$-test was used.

\section{Results.}

Monkeys. - During the neonatal period (1 to 3 months) the Leydig cells represented $9.6 \%( \pm 0.9)$ of the whole interstitial cell population. Most other cells were fibroblast-like cells of varying shape and size but some macrophages and mast cells were also encountered. The mitotic figures were extremely few but the cell type was rarely reliably identified with light microscopy. After ultrastructural observation of adjacent thin sections, Leydig cells in mitosis $(2.3 \% \pm 0.3)$ could be identified (fig. 1$)$, as well as mitoses in fibroblast-like cells $(0.44 \% \pm \pm 0.06)$. In infants and prepubertals, the percentage of Leydig cells remained practically constant $(9.2 \pm 0.9 ; 9.4 \pm 0.8)$; it fell significantly $(6.0 \pm 0.2, P<0.025)$ in pubertals but did not change further in adults. In spite 

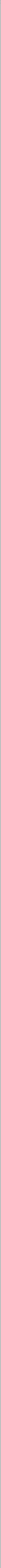
of the very large number of interstitial cells examined from infancy to adulthood, no mitotic figures were detected in any cell type.

The incorporation of ${ }^{3} \mathrm{H}$-thymidine in interstitial cells of 2 neonates and 2 adult monkeys was estimated by radioautography of semi-thin sections; ultrastructural observation of adjacent thin sections was used to ascertain the identity of the labeled cells (figs. 2, 3). As clearly shown in table 1, some Leydig cells and fibroblast-like cells were labeled 1 to $4 \mathrm{~h}$ after ${ }^{3} \mathrm{H}$-thymidine injection, and a significant increase of the labeling indices was noted 7 to 15 days later. Only single labeled cells were seen initially, whereas about half of the labeled cells observed later were found in pairs (fig. 2). A greater proportion of pairs of labeled cells might have been expected if numerous adjacent sections had been analysed systematically.

TABLE 2

Percentage (\%) and mitotic index (m.i.) of interstitial cells in rats.

\begin{tabular}{|c|c|c|c|c|}
\hline \multicolumn{2}{|c|}{ Age } & Prepubertals & Pubertals & Postpubertals \\
\hline$n$ & & 28 days & 45 days & 63 days \\
\hline \multirow{2}{*}{ Leydig cells } & $\%$ & $28.6 \pm 1.2$ & $38.6 \pm 0.8^{*}$ & $38 \pm 1.1$ \\
\hline & m.i. & $1.9 \pm 0.1$ & $0.2 \pm 0.04^{*}$ & - \\
\hline \multirow{2}{*}{ Other cells } & $\%$ & $71.4 \pm 1.2$ & $61.4 \pm 0.8^{*}$ & $62 \pm 1.1$ \\
\hline & m.i. & $0.4 \pm 0.02$ & $0.13 \pm 0.02^{*}$ & - \\
\hline
\end{tabular}

* values significantly different $(P<0.001)$ compared to the preceding stage.

Rats. - In the younger rats studied (28 days), the population of interstitial cells consisted of Leydig cells ( $30 \%)$, myoid cells, fibroblast-like cells of varying shape and size and macrophages. Mitoses were frequently encountered but, as in monkeys, some mitotic cells were not reliably identified in semi-thin sections. The mitotic figures were easily classified after ultrastructural observation of the adjacent thin sections (table 2). Most of these mitoses occurred in mature Leydig cells (figs. 4, 5, 6) but also in myoid cells and fibroblast-like cells. In subadult rats

\section{PLATE I}

FIGS. 1 to 3. - Monkey Leydig cel/s.

1. This mitotic cell in a neonate monkey shows an abundant smooth endoplasmic reticulum and mitochondria with tubular cristae characteristic of mature Leydig cells. $\times 9,000$.

2. In an adult monkey, 10 days after injection of ${ }^{3} \mathrm{H}$-thymidine, labeled Leydig cells are often observed in pairs. A Sertoli cell (S) rich in lipid droplets is indicated in the neighbouring seminiferous tubule. $\times 6,000$.

3. An adjacent section of the right Leydig cell seen in figure 2 has been enlarged to show the typical organelle and the silver grains over the nucleus. $\times 20,000$. 
(45 days), the percentage of Leydig cells was significantly increased $(P<0.001$ ) but their mitotic activity was dramatically decreased $(P<0.001)$ as in the other interstitial cells. No mitoses were detected in postpubertal animals.

\section{Discussion.}

Leydig cells have a biphasic pattern of development. It is admitted that, during their two growth periods, new Leydig cells may arise by differentiation of stem cells and also by division of mature cells (Christensen, 1975). The differentiation process of Leydig cells is documented in a number of species (see Introduction for references), but it remains speculative, and the identity of stem cells is still controversial. Likewise, the mitotic activity of Leydig cells is often invoked but is still to be clearly demonstrated. For example, mitoses in Leydig cells have been reported in the fetuses and young of rats (Roosen-Runge and Anderson, 1959) and in young mice (Baillie, 1961; Hitzeman, 1962) but mitotic cells were not actually identified in paraffin sections. The incorporation of ${ }^{3} \mathrm{H}$ thymidine in presumptive Leydig cells of young rats was also observed in paraffin sections (Niemi and Kormano, 1964; Okada, 1970), whereas no labeling was detected at the same age (1 to 21 days) in semi-thin plastic sections (Orth, 1982). these different results might be related to preparative methods but more probably to Leydig cell identification which was more reliable in the latter work.

A number of experimental models have been developed in rats, inducing either Leydig cell hyperplasia (Chemes et al., 1976 ; Aoki and Fawcett, 1978 ; Kerr et al., 1979 ; Christensen and Peacock, 1980) or destruction followed by extensive regeneration (Kerr et al., 1985b ; Morris et al., 1986 ; Jackson et al., 1986 ; Risbridger et al., 1987). Most of these studies claimed, but did not show, that Leydig cell mitotic activity might account for their increase in number. Chemes et al. (1976) provided evidence for a correlation between interstitial cell mitosis and the increase in Leydig cell number detected in paraffin sections, but only Kerr et al. (1979) identified mitotic Leydig cells using the electron microscope.

Thus, the problem of the mitotic activity of mature Leydig cells has not been clearly resolved because mitotic figures were rarely reported and not convincingly identified. During testicular development the interstitial cell population changes considerably, showing varying proportions of mesenchymal or fibroblast-like cells, differentiating or immature Leydig cells, mature cells and also myoid cells,

\section{PLATE ॥}

FIGS. 4 to 5. - Mitoses in Leydig cells of 28-day rats.

4. Part of two seminiferous tubules (ST) surrounded by myoid cells (m) and a dividing interstitial cell identified as a Leydig cell at higher magnification. $\times 6,000$.

5. Prophase in a typical Leydig cell. $\times 12,600$.

6. Part of a late telophase in a Leydig cell filled with abundant SER and characteristic mitochondria. A small portion of a macrophage $(M)$ is also visible. $\times 20,000$. 
macrophages and mast cells. Most of these cell types are potential candidates for mitotic activity. With a light microscope, the characteristics distinguishing certain interphasic cell types, for example mature Leydig cells and their possible precursors, are not very evident, and are even less so when the cells are in mitosis. Indeed, in such an heterogeneous population of interstitial cells ultrastructural observation had to be used to identify the mitotic Leydig cells ; this type of observation was also useful in ascertaining the identity of some ${ }^{3} \mathrm{H}$ thymidine-labeled cells. Therefore, in the present work using both light and electron microscopy of successive sections, errors in the estimation of mitotic indices and labeling indices were greatly minimized.

In monkeys, both direct (mitotic figures) and indirect $\left({ }^{3} \mathrm{H}\right.$-thymidine labeling) evidence of Leydig cell mitotic ability was obtained in the young. In adults, as previously reported (Fouquet and Raynaud, 1985), only labeled cells were observed. However, owing to the greater number of cells carefully examined in better conditions, it has been possible, in the present work, to demonstrate with certainty a significant increase in their labeling indice with increasing time. This fact and the occurrence of pairs of labeled cells strongly suggest that Leydig cells are also able to divide in adult monkeys.

In rats, simple ultrastructural observation was sufficient to demonstrate mitoses in mature Leydig cells during pubertal development. Except for this growing adult generation of Leydig cells, there is no evidence for mitoses in the Leydig cells of younger rats (Orth, 1982) and sexually mature animals. However, in adult rats isolated Leydig cells were shown to synthesize DNA (Abney and Carswell, 1986), suggesting renewal ability.

It is not known if mitoses also occur in the Leydig cells of other species, except in humans where mitotic figures have been identified in adult testes (Amat et al., 1986). Taken together these recent results support the concept of the selfrenewal of mature Leydig cells.

Reçu en juin 1987

Accepté en septembre 1987.

Acknowledgements. - The authors wish to thank Miss Annie Gonzales for skillful technical radioautographic assistance.

Résumé. Activité mitotique des cellules de Levdig chez le singe et le rat.

Des testicules de singes (Macaca fascicularis), de la naissance à la maturité sexuelle et, de rat en périodes pubertaire et adulte ont été examinés par microscopie optique et électronique afin d'estimer l'activité mitotique des cellules de Leydig. Chez le singe, une activité mitotique n'est mesurable que chez les nouveau-nés (0-3 mois) : $2,3 \%$ pour les cellules de Leydig et $0,4 \%$ pour les cellules de type fibroblaste. Comme le montre l'incorporation de thymidine tritiée, des cellules de Leydig matures sont marquées chez le nouveau-né $(2 \%)$ et l'animal adulte $(1 \%)$. Les indices de marquages augmentent significativement avec l'augmentation du temps succédant à l'exposition au précurseur et, des paires de cellules marquées sont alors observées. Chez les rats en développement pubertaire à 28 et 45 jours les index mitotiques sont respectivement : $2 \%$ et $0,2 \%$ pour les cellules de Leydig ; $0,4 \%$ et $0,1 \%$ pour les cellules myoïdes et de type fibroblaste. Les 
mitoses ne sont pas décelables chez les rats postpubères (63 jours). Au total, ces résultats démontrent la capacité de multiplication des cellules de Leydig matures au cours du développement normal.

\section{References}

ABNEY T. O., CARSWELL L. S., 1986. Gonadotropin regulation of Leydig cell DNA synthesis. Molec. cell. Endocr., 45, 157-165.

AMAT P., PANIAGUA R., NISTAL M., MARTIN A., 1986. Mitosis in adult human Leydig cells. Cell Tiss. Res., 243, 219-221.

AOKI A., FAWCETT D. W., 1978. Is there a local feedback from the seminiferous tubules affecting activity of the Leydig cells? Biol. Reprod., 19, 144-158.

BAILLIE A. H., 1961. Observation on the growth and histochemistry of the Leydig tissue in the postnatal prepubertal mouse testis. J. Anat., 95, 357-370.

CAMATINI M., FRANCHI E., 1981. Postnatal differentiation of Leydig cells in the African green monkey. Amer. J. Primatol., 1, 231-239.

CHEMES H. E., RIVAROLA M. A., BERGADA C., 1976. Effect of HCG on the interstitial cells and androgen production in the immature rat testis. J. Reprod. Fert., 46, 279-282.

CHRISTENSEN A. K., 1975. Leydig cells, In GREEP R. O., ASTWOOD E. B., Handbook of physiology, Amer. Physiol. Soc., Washington, $5, n^{\circ} 7,57-94$.

CHRISTENSEN A. K., PEACOCK K., 1980. Increase in Leydig cell number in testes of adult rats treated chronically with an excess of human chorionic gonadotropin. Biol. Reprod., 22, 383391.

FOUQUET J. P., 1987. Ultrastructural analysis of a local regulation of Leydig cells in the adult monkey (Macaca fascicularis) and rat. J. Reprod. Fert., 79, 49-56.

FOUQUET J. P., MEUSY-DESSOLLE N., DANG D. C., 1983. Morphometry of fetal Leydig cells in the monkey (Macaca fascicularis), correlation with plasma testosterone. Biol. Cell, 49, 267272.

FOUOUET J. P., MEUSY-DESSOLLE N., DANG D. C., 1984. Relationships between Leydig cell morphometry and plasma testosterone during postnatal development of the monkey (Macaca fascicularis). Reprod. Nutr. Dévelop., 24, 281-296.

FOUQUET J. P., RAYNAUD F., 1985. Renewal of Leydig cells in the neonatal and adult monkey : a radioautographic study. Biol. Cell, 54, 187-190.

GONDOS B., MORRISON K. P., RENSTON R. H., 1977. Leydig cell differentiation in the prepubertal rabbit testis. Biol. Reprod., 17, 745-748.

HITZEMAN S. J. W., 1962. Development of enzyme activity in the Leydig cells of the mouse testis. Anat. Rec., 143, 351-362.

JACKSON A. E., O'LEARY P. C., AYERS M. M., de KRETSER D. M., 1986. The effects of ethylene dimethane sulfonate (EDS) on rat Leydig cells : evidence to support a connective tissue origin of Leydig cells. Biol. Reprod., 35, 425-437.

KERR J. B., RICH K. A., de KRETSER D. M., 1979. Alterations of the fine structure and androgen secretion of the interstitial cells in the experimentally cryptorchid rat testis. Biol. Reprod., 20, 409-422.

KERR J. B., ROBERTSON D. M., de KRETSER D. M., 1985a. Morphological and functional characterization of interstitial cells from mouse testes fractionated on percoll density gradients. Endocrinology, 116, 1030-1043.

KERR J. B., DONACHIE K., ROMMERTS F. F. G., 1985b. Selective destruction and regeneration of rat Leydig cells in vivo. A new method for the study of seminiferous tubular-interstitial tissue interaction. Cell Tiss. Res., 242, 145-156.

MORRIS I. D., PHILLIPS D. M., BARDIN C. W., 1986. Ethylene dimethane sulfonate destroys Leydig cells in the rat testis. Endocrinology, 118, 709-719.

NIEMI M., KORMANO M., 1964. Cell renewal in the interstitial tissue of postnatal prepubertal rat testis. Endocrinology, 74, 996-998.

OKADA K., 1970. Experimental study on the proliferation and the maturation of germ-cell, Sertoli cell and Leydig cell of the rat testis. Jap. J. Urol., 61, 1125-1146. 
ORTH J. M., 1982. Proliferation of Sertoli cells in fetal and postnatal rats : a quantitative autoradiographic study. Anat. Rec., 203, 485-492.

PRINCE F. P., 1984. Ultrastructure of immature Leydig cells in the human prepubertal testis. Anat. Rec., 209, 165-176.

RISBRIDGER G. P., KERR J. B., de KRETSER D. M., 1987. Influence of the cryptorchid testis on the regeneration of rat Leydig cells after administration of ethane dimethane sulfonate. $J$. Endocr., 112, 197-204.

ROOSEN-RUNGE E. C., ANDERSON D., 1959. The development of the interstitial cells in the testis of the albino rat. Acta Anat. (Basel), 37, 125-137.

SCHULZE C., 1984. Sertoli cells and Leydig cells in man. Adv. Anat. Embryol. Cell Biol., 88. Springer, Berlin. Heidelberg. New York, Tokyo. 